\title{
MEMBANGUN INDONESIA DARI DAERAH DENGAN PENGUATAN PARTISIPASI MASYARAKAT
}

\author{
I Wayan Sutrisna \\ Fakultas Ilmu Sosial dan Ilmu Politik Universitas Mahendradatta - Denpasar \\ e-mail : sutrisna76@yahoo.co.id
}

\begin{abstract}
Abstrak, Pembangunan nasional memiliki tujuan multidimensional yang salah satunya adalah mewujudkan masyarakat Indonesia yang demokratis, karena dengan keadaan yang lebih demokratis memungkinkan masyarakat lebih terbuka untuk berpartisipasi dalam pembangunan di segala bidang Perkembangan pembangunan yang semakin cepat dan sangat kompleks menuntut seluruh komponen yang terlibat dalam proses pembangunan dan demokrasi mampu mewujudkan apa yang menjadi tujuan dari pembangunan nasional. Partisipasi masyarakat dalam proses pembangunan di Indonesia pada umumnya saat ini masih sangat rendah. Masyarakat masih enggan untuk terlibat secara langgsung dalam seluruh proses baik itu perencanaan, pelaksanaan maupun evaluasi pembangunan yang dilaksanakan oleh pemerintah. Rendahnya partisipasi ini akibat dari kebijakan pemerintah yang masih kurang dalam memberikan ruang bagi setiap warga Negara untuk berpartisipasi dalam pembangunan. Pelaksanaan Musyawarah Perencanaan Pembangunan (Musrenbang) mulai pada tingkat desa hingga nasional dianggap oleh sebagaian masyarakat hanya proses serimonial belaka. Pembangunan Nasional yang berbasis pemberdayaan masyarakat akan terwujud apabila pemerintah memiliki keinginan yang kuat untuk melaksanakannya. Pemerintah mendorong dan memberikan kesempatan kepada masyarakat untuk terlibat dalam pola partisipatif ini. Pola ini membuat masyarakat semakin berdaya dan ikut menikmati kue pertumbuhan ekonomi yang dihasilkan dari proses pembangunan yang dilaksankan. Pertumbuhan ekonomi yang berkualitas menjadikan pembangunan yang dilaksanakan oleh pemerintah bersama seluruh komponen bangsa mampu meningkatkan kesejahteraan masyarakat secara luas sesuai dengan apa yang menjadi tujuan dari pada pembangunan nasional itu sendiri. Pembangunan nasional yang diimbangi dengan partisipasi masyarakat yang aktif atau dengan masyarakat yang berdaya akan menghasilkan kekuatan yang mampu mewujudkan tujuan nasional sesuai yang di cita-citakan.. Mendorong partisipasi masyarakat dalam membangun Indonesia dari daerah akan terwujud apabila pemerintah memiliki keinginan yang baik untuk melaksanakannya. Pemerintah wajib mendorong dan memberikan kesempatan kepada masyarakat untuk terlibat dalam pola partisipatif ini. Pola ini membuat masyarakat semakin berdaya dan ikut menikmati kue pertumbuhan ekonomi yang dihasilkan dari proses pembangunan yang dilaksankan
\end{abstract}

Kata kunci : pembangunan, otonomi dan partisipasi.

Abstract, National development has a multidimensional goal, one of which is to realize a democratic Indonesian society, because with a more democratic condition, it allows the public to be more open to participate in development in all fields. The development of faster and more complex development demands all components involved in the development process and democracy able to realize what is the goal of national development.

Community participation in the development process in Indonesia in general is currently very low. The community is still reluctant to engage in a continuous manner in the entire process of development planning, implementation and evaluation carried out by the government. This low participation is a result of government policies that are still lacking in providing space for every citizen to participate in development. The implementation of the Development Planning Conference (Musrenbang) starting at the village level up to the national level is considered by some as merely a serimonial process. National development based on community empowerment will be realized if the government has a strong desire to implement it. The government encourages and provides opportunities for the public to be involved in this participatory pattern. This pattern makes the community more empowered and participates in enjoying the cake of economic growth resulting from the development process that is carried out. Quality economic growth makes development carried out by the government together with all components of the nation able to improve the welfare of society at large in accordance with what is the goal of national development itself. National development balanced with active community 
participation or empowered communities will produce a force capable of realizing national goals according to their goals. Encouraging community participation in developing Indonesia from the regions will be realized if the government has a good desire to implement it. The government must encourage and provide opportunities for the public to be involved in this participatory pattern. This pattern makes the community more empowered and participates in enjoying the cake of economic growth resulting from the development process that is carried out

Keywords: development, autonomy and participation.

\section{A. Pendahuluan}

Tujuan Pelaksanaan Pembangunan yang dilakukan oleh pemerintah Indonesia adalah untuk mewujudkan kesejahteraan masyarakat secara menyeluruh. Pembangunan Nasional di Negara Kesatuan Republik Indonesia (NKRI) dilaksanakan untuk mewujudkan Tujuan nasional seperti yang termuat dalam pembukaaan Undang-Undang Dasar Negara Republik Indonesia Tahun 1945 alinia IV yaitu "melindungi segenap bangsa Indonesia dan seluruh tumpah darah Indonesia dan untuk memajukan kesejahteraan umum, mencerdaskan kehidupan bangsa, dan ikut melaksanakan ketertiban dunia yang berdasarkan kemerdekaan, perdamaian abadi dan keadilan sosial". Pembangunan Nasional dilaksanakan sebagai usaha untuk meningkatkan seluruh aspek kehidupan masyarakat, bangsa dan negara yang sekaligus merupakan proses pengembangan dan pemberdayaan seluruh komponen dalam kehidupan bernegara guna mewujudkan tujuan nasional yang dicita-citakan sejak awal kemerdekaan.

S.P Siagian, (1983), mendifinisikan pembangunan sebagai suatu usaha atau rangkaian usaha pertumbuhan dan perubahan yang berencana yang dilakukan secara sadar oleh suatu bangsa, negara dan pemerintah, menuju modernitas dalam rangka pembinaaan bangsa (Nation-Building). Ide pokok dalam pengertian pembangunan yakni pembangunan merupakan suatu proses, usaha yang secara sadar dilakukan, serta dilaksanakan secara berencana, dan mengarah kepada modernitas. Selain itu usaha pembangunan yang dilaksanakan ditujukan kepada usaha pembinaan bangsa yang terus menerus dalam rangka mencapai tujuan bangsa dan negara yang telah ditentukan sebelumnya.

$$
\text { Pembangunan nasional pada }
$$

hakekatnya adalah pembangunan yang dilaksanakan secara merata untuk seluruh masyarakat dan wilayah Indonesia. Pembangunan dilaksanakan bersama oleh masyarakat dan pemerintah. Masyarakat adalah pelaku utama pembangunan dan pemerintah berkewajiban mengarahkan, membimbing serta menciptakan suasana yang menunjang kelancaran proses pembangunan. Kegiatan masyarakat dan pemerintah harus saling mendukung, saling mengisi dan saling melengkapi dalam satu kesatuan gerak menuju tercapainya satu tujuan yakni tujuan pembangunan nasional.

Pembangunan di Indonesia memiliki tujuan multidimensional yang salah satunya adalah mewujudkan masyarakat Indonesia yang demokratis, karena dengan keadaan yang 
lebih demokratis memungkinkan masyarakat lebih terbuka untuk berpartisipasi dalam pembangunan di segala bidang Perkembangan pembangunan yang semakin cepat dan sangat kompleks menuntut seluruh komponen yang terlibat dalam proses pembangunan dan demokrasi mampu mewujudkan apa yang menjadi tujuan dari pembangunan nasional.

$$
\text { Ditengah hingar bingarnya }
$$

pelaksanaan pembangunan yang telah dilaksanakan, masih terdapat banyak permasalahan yang dihadapi meski saat ini pertumbuhan ekonomi Indonesia sudah tinggi. Masalah yang masih sangat krusial yang dihadapi dalam proses pembangunan nasional yakni belum meratanya hasil pembangunan bagi seluruh wilayah Indonesia, terlalu tinggi kesenjangan antara pembangunan di Indonesia bagian barat khusunya Jawa dengan daerah Indonesia Tengah dan Timur. Hasil-hasil pembangunan belum merata dinikmati oleh seluruh anak bangsa. Bahkan ada daerah yang sumbangan pajaknya sangat tinggi bagi negara karena memiliki hasil tambang yang besar malahan daerahnya sebagaian besar merupakan daerah tertinggal. Situasi seperti ini mengakibatkan riak-riak perlawanan dari daerah menuntut keadilan dan pemertaan pembangunan. Wilayah seperti Papua, Sumbawa, dan Kalimantan yang telah memberikan sumbangan sangat besar khusunya pajak pertambangan malah banyak menyimpan kantong-kantong kemiskinan yang merupakan cerminan dari keterbelakangan dalam hasil pembangunan nasional.

Keterlibatan atau partisipasi masyarakat juga belum maksimal dalam proses pembangunan nasional. Pemberdayaan masyarakat masih hanya sebatas slogan dan belum dilaksanakan secara optimal. Proses pembangunan belum melibatkan seluruh komponen masyarakat, masih dikendalikan oleh segelitir "elite" saja. Mayoritas masyarakat belum dilibatkan dalam seluruh proses yang dilaksanakan. Keterlibatan masyarakat atau pemberdayaan masyarakat dalam seluruh proses pembangunan saat ini mutlak diperlukan, baik itu mulai dari proses perencanaan, pengorganisasian hingga proses evaluasi dan pengawasan.

\section{B. Hambatan dalam mewujudkan Pembangunan Partisipatif}

Partisipasi masyarakat merupakan salah satu indikator dalam pelaksanaan prinsipprinsip good governance. Dalam pembangunan yang partisipatif, semua warga masyarakat mempunyai suara yang sama dalam pengambilan keputusan, baik secara langsung maupun melalui lembaga-lembaga perwakilan sah yang mewakili kepentingan mereka. Partisipasi dibangun berdasarkan kebebasan berkumpul dan mengungkapkan pendapat, serta kapasitas untuk berpartisipasi secara konstruktif. Partisipasi bermaksud untuk menjamin agar setiap kebijakan yang diambil mencerminkan aspirasi masyarakat. Dalam rangka mengantisipasi berbagai isu yang ada, pemerintah menyediakan saluran komunikasi agar masyarakat dapat mengutarakan pendapatnya. Jalur komunikasi ini meliputi pertemuan umum, temu wicara, konsultasi dan penyampaian pendapat secara tertulis. Bentuk lain untuk merangsang keterlibatan masyarakat adalah melalui perencanaan partisipatif untuk 
menyiapkan agenda pembangunan, pemantauan, evaluasi dan pengawasan secara partisipatif dan mekanisme konsultasi untuk menyelesaikan isu sektoral.

Mewujudkan pembangunan yang partisipatif bukanlah merupakan hal yang mudah, karena partisipasi akan terwujud apabila masyarakat dengan kesadaran yang tinggi mau melibatkan diri dalam proses pembangunan yang dilaksanakan. Dalam mewujudkan pembangunan partisipatif terdapat beberapa hambatan yang berasal dari faktor internal dan eksternal. Hambatanhambatan yang dihadapi dalam mewujudkan pembangunan partisipatif seperti yang dikemukakan oleh Wa Ode Harlena Astuti Unga dalam Wiratma (2007) adalah sebagai berikut :

\section{Citra Birokrasi}

Ada semacam sikap yang terbentuk di kalangan para birokrat di Indonesia yang merasa diri bahwa pemerintah merupakan institusi yang sangat baik. Pemerintah telah melaksanakan pembangunan bagi masyarakat. Oleh karena itu masyarakat harus tunduk, taat dan loyal kepada pemerintah. Hal ini menyebabkan tidak terjadinya dorongan keinginan untuk berpartisipasi yang sangat diperlukan dalam rangka pengembangan demokrasi dan pelaksanaan pembangunan. Partisipasi yang diharapkan sulit terwujud karena pemerintah/birokrasi tidak memberikan ruang yang luas bagi masyarakat untuk terlibat dalam proses pembangunan.

\section{Faktor Sosial-Ekonomik}

Partisipasi masyarakat di Indonesia tidak dapat dilepaskan dari kondisi sosial masyarakat yang tentu saja sangat berpengaruh terhadap keterlibatan mereka dalam pelaksanaan pembangunan, baik secara individual maupun secara institusional. Masyarakat yang masih lemah tingkat sosial ekonominya tentu saja akan lemah pula partisipasinya dalam pelaksanaan pembangunan, karena masyarakat tersebut akan lebih mementingkan memenuhi kebutuhan pokok terlebih dahulu baru aktif dalam proses kegiatan pembangunan.

3. Belum adanya persamaan pemahaman mengenai konsep partisipasi oleh pihak perencana dan pelaksana pembangunan.

Definisi partisipasi yang berlaku dikalangan aparat perencana dan pelaksana pembangunan adalah kemauan rakyat untuk mendukung secara mutlak program-program pemerintah yang dirancang dan ditentukan tujuannya oleh pemerintah. Para perencana dan pelaksana menggunakan suatu konsep hierarkis dalam menyeleksi proyek pembangunan. Proyek-proyek pembangunan yang bersal dari pemerintah diistilahkan sebagai proyek pembangunan yang dibutuhkan oleh rakyat, sedangkan proyek pembangunan yang diusulkan oleh rakyat dianggap sebagai keinginan.

4. Pembangunan dijadikan sebagai idiologi.

Sebagai suatu idiologi maka pembangunan harus diamankan dan dijaga dengan ketat. Pengamanan yang ketat terhadap pembangunan menimbulkan reaksi balik dari masyarakat yang merugikan usaha membangkitkan kemauan rakyat untuk berpartisipasi dalam proses pelaksanaan pembangunan. Dikalangan masyarakat muncul 
budaya diam yang salah satu perwujudannya adalah keengganan masyarakat untuk mengevaluasi proses pembangunan secara kritis dan terbuka. Hal ini dapat menyebabkan lemahnya keinginan masyarakat untuk turut berpartisipasi dalam proses peleksanaan pembangunan.

Hambatan lainnya dalam mewujudkan pembangunan partisipatif yang masih terjadi saat ini adalah sikap acuh masyarakat dalam proses pembangunan. Masyarakat selalu nerima apapun keputusan yang diambil oleh pemerintah, sehingga banyak sekali programprogram yang dilaksanakan jauh dari kepentingan masyarakat. Masyarakat kebanyakan tidak berusaha melibatkan diri dalam setiap proses pembangunan. Kadang juga para "elite" mempersempit pintu partisipasi sehingga mayoritas masyarakat tidak terlibat dalam proses yang ada.

\section{Strategi Penguatan Partisipasi Masyarakat}

Partisipasi masyarakat dalam proses pembangunan di Indonesia pada umumnya saat ini masih sangat rendah. Masyarakat masih enggan untuk terlibat secara langgsung dalam seluruh proses baik itu perencanaan, pelaksanaan maupun evaluasi pembangunan yang dilaksanakan oleh pemerintah. Rendahnya partisipasi ini akibat dari kebijakan pemerintah yang masih kurang dalam memberikan ruang bagi setiap warga Negara untuk berpartisipasi dalam pembangunan. Pelaksanaan Musyawarah perencanaan Pembangunan (Musrenbang) mulai pada tingkat desa hingga nasional dianggap oleh sebagaian masyarakat hanya proses serimonial belaka.

Tujuan utama dari proses pembangunan yang dilaksanakan oleh pemerintah adalah menuju pada kesejahteraan masyarakat. Masyarakat yang sejahtera akan terus diupayakan oleh pemerintah melalui berbagai macam pembangunan. Pembangunan partisipatif merupakan salah satu strategi dalam mewujudkan kesejahteraan tersebut. Partisipasi masyarakat dalam proses pembangunan merupakan kunci utama suksesnya pelaksanaaan pembangunan tersebut. Partisipasi masyarakat akan menempatkan masyarakat sebagai motor penggerak atau sebagai subyek pembangunan bukan hanya sebagai obyek atau penerima manfaat saja. Dengan Partisispasi ini membuat masyarakat akan merasa memiliki serta ikut bertanggungjawab terhadap setiap proses dan hasil-hasil pembangunan. Partisipasi masyarakat akan mengarah kepada pemberdayaan masyarakat karena melalui partisipasi dalam seluruh proses, masyarakat akan semakin berdaya dan mampu mengendalikan proses tersebut kearah pencapaian kesejahteraan masyarakat itu sendiri.

Dalam penguatan pembangunan partisipatif, Mahbub Amiruddin dalam Wiratma (2007) menyebutkan terdapat tiga strategi ideal yaitu :

1. Kekuasaan legal dan legitimit

Adanya kebutuhan untuk bekerjanya suatu tata kekuasaan yang mendukung atau memiliki komitmen mengenai realisasi pemerdayaan masyarakat yang konsisten. 
2. Kebijakan-kebijakan yang mendukung

Suatu legalitas formal sangat dibutuhkan terutama untuk membenarkan menjadi dasar hukum dan sekaligus mampu menjadi payung gerakan penguatan dan pemberdayaan masyarakat. Kebijakan ini sudah tentu bukan kebijakan yang eksklusif melainkan kebijakan yang disusun secara partisipatif dan dilakukan bersama-sama dengan para pihak yang terkait.

3. Dukungan dari massa rakyat yang sadar dan terhimpun.

Strategi ini sekaligus akan mendapatkan kemudahan-kemudahan dalam melakukan penguatan dan pemberdayaan masyarakat, antara lain adanya keabsahan dan kemudahan. Dukungan dari rakyat ini juga akan menjadi penyangga sekaligus kontrol atas massa rakyat sehingga tujuan yang akan dicapai sesuai dengan apa yang dikehendaki oleh masyarakat. Dukungan ini bisa lahir apabila massa dalam keadaan dan kondisi yang sadar dan terhimpun atau terorganisir.

Suhandak (2007) menyebutkan bahwa ada lima jenis partisipasi masyarakat dalam pembangunan yakni :

1. Ikut memberi input proses pembangunan, menerima imbalan atas input tersebut, dan ikut menikmati hasilnya.

2. Ikut memberi input dan menerima hasilnya.

3. Ikut memberi input dan menerima imbalan tanpa ikut menikmati hasil pembangunan secara langsung.

4. Menikmati atau memanfaatkan hasil pembangunan tanpa ikut memberikan input.
5. Memberi input tanpa menerima imbalan dan tidak menikmati hasilnya.

Memberikan kesempatan yang luas dan manfaat yang maksimal kepada masyarakat dalam proses pembangunan merupakan cara yang efektif meningkatkan partisipasi masyarakat dalam kegiatan pemerintahan dan pembangunan. Masyarakat akan merasa memiliki dan berusaha terlibat dalam setiap proses yang dilaksanakan. Perencanaan pembangunan yang partisipatif dengan melibatkan masyarakat secara maksimal akan berdampak pada maksimalnya pencapaian tujuan dari pembangunan itu sendiri.

\section{Partisipasi Publik di era Otonomi Daerah}

Partisipasi masyarakat dalam proses pemerintahan dan pembangunan merupakan hal yang harus dilakukan diera pembangunan yang modern ini. Partisipasi yang berarti peran aktif dan pelibatan seluruh masyarakat dalam peoses pembangunan akan mampu mewujudkan hasil pembangunan yang mampu dinikmati oleh mayoritas masyarakat. Gemerlapnya hasil pembangunan yang kita lihat di kota-kota besar ternyata belum diimbangi dengan pemerataan pembangunan di seluruh pelosok negeri. Pemerintah saat ini masih banyak menyisakan kantong-kantong kemiskinan khusunya di daerah-daerah pedesaan.

Anggapan keberhasilan pemerintahan dengan hanya mengukur tingginya pertumbuhan ekonomi setiap tahun oleh pemerintah yang berkuasa merupakan hal yang belum mampu membawa masyarakat kearah 
kemakmuran. Secara statistik pertumbuhan ekonomi negara kita memang cukup tinggi bahkan termasuk diantara pertumbuhan ekonomi tinggi diantara negara-negara di dunia yang sebagain besar masih mengalami krisis ekonomi. Namun pertumbuhan yang tinggi ini belum dibarengi dengan pertumbuhan yang berkualitas dimana pertumbuhan ini hanya dinikmati oleh segelintir masyarakat saja. Pertumbuhan ekonomi yang tinggi tapi tidak berkualitas mengakibatkan semakin lebarnya jurang pemisah antara si-miskin dengan sikaya. Para pengusaha besar mampu menikmati pertumbuhan ekonomi ini dengan semakin bertambahnya pundi-pundi kekayaannya. Sedangkan rakyat miskin khusunya di pedesaan semakin menderita akibat keadaan yang membelenggu mereka.

Salah satu kebijakan yang dikeluarkan dalam mendorong parisipasi masyarakat dalam pembangunan adalah kebijakan desentralisasi. Melalui kebijakan desentralisasi, pembangunan dilaksanakan dan disesuaikan oleh masingmasing daerah dengan menggali sumbersumber daya daerah serta memperhatikan kearifan lokal daerah. Pemberian wewenang kepada daerah diharapkan menjadi motivasi kepada seluruh komponen masyarakat di daerah untuk ikut serta berpartisipasi dalam seluruh proses pembangunan yang dilaksanakan oleh pemerintah. Partisipasi ini akan mampu menjadi kekuatan yang luar biasa dalam mensukseskan pembangunan itu sendiri. Dalam Undang-Undang Nomor 23 tahun 2014 tentang Pemerintahan Daerah disebutkan bahwa Otonomi Daerah adalah hak, wewenang, dan kewajiban daerah otonom untuk mengatur dan mengurus sendiri Urusan Pemerintahan dan kepentingan masyarakat setempat dalam sistem Negara Kesatuan Republik Indonesia.

Secara teoritis, menurut Mardiasmo (2018), desentralisasi akan menghasilkan dua manfaat nyata. Pertama, mendorong prakarsa dan kreativitas masyarakat dalam pembangunan serta mendorong pemerataan hasil-hasil pembangunan di seluruh daerah dengan memanfaatkan sumber daya dan potensi yang tersedia di masing-masing daerah. Kedua, memperbaiki alokasi sumber daya produktif melalui pergeseran peran pengambilan keputusan publik ke tingkat pemerintahan yang paling rendah yang memiliki informasi yang paling lengkap. Kebijakan desentralisasi akan menghasilkan wadah bagi masyarakat setempat untuk berperan serta dalam menentukan caracaranya sendiri untuk meningkatkan taraf hidupnya sesuai dengan peluang dan tantangan yang dihadapi dalam ikatan Negara Kesatuan Republik Indonesia (NKRI).

Mendorong partisipasi masyarakat dalam membangun Indonesia dari daerah akan terwujud apabila pemerintah memiliki keinginan yang kuat untuk melaksanakannya. Pemerintah wajib mendorong dan memberikan kesempatan kepada masyarakat untuk terlibat dalam pola partisipatif ini. Pola ini membuat masyarakat semakin berdaya dan ikut menikmati kue pertumbuhan ekonomi yang dihasilkan dari proses pembangunan yang dilaksankan. Pertumbuhan ekonomi yang berkualitas menjadikan pembangunan yang dilaksanakan oleh pemerintah bersama seluruh komponen bangsa mampu meningkatkan kesejahteraan masyarakat secara luas sesuai 
dengan apa yang menjadi tujuan dari pada pembangunan.

E. Pembangunan Nasional dan masyarakat yang berdaya.

Tujuan mulia dari kebijakan desentralisasi ini adalah pemertaan pembangunan yakni pembangunan dilaksanakan dan disesuaikan oleh masingmasing daerah dengan menggali sumbersumber daya daerah serta memperhatikan kearifan lokal daerah. Pemberian wewenang kepada daerah diharapkan menjadi motivasi kepada seluruh komponen masyarakat di daerah untuk ikut serta berpartisipasi dalam seluruh proses pembangunan yang dilaksanakan oleh pemerintah. Partisipasi ini akan mampu menjadi kekuatan yang luar biasa dalam mensukseskan pembangunan itu sendiri.

Hal-hal yang mendasar dalam pelaksanaan otonomi daerah adalah adanya upaya untuk mendorong pemberdayaan masyarakat, pengembangan prakarsa dan kreativitas, peningkatan peran serta masyarakat serta pengembangan peran dan fungsi DPRD.(Mardiasmo, 2018).

Hakim (2011) mengungkapkan bahwa paradigma pembangunan manusia sebagai konsep yang holistik, mempunyai empat unsur penting, yakni (1) peningkatan produktivitas;

pemerataan kesempatan;

kesinambungan pembangunan;

pemberdayaan masyarakat. Konsep ini diprakarsai dan ditunjang oleh United Nation Develeopment Program (UNDP) yang mengembangkan Indeks Pembangunan Manusia. Indeks ini merupakan indikator gabungan yang terdiri dari tiga ukuran yaitu kesehatan, pendidikan dan tingkat pendapatan riil.

Pembangunan Nasional yang berbasis pemberdayaan masyarakat akan terwujud apabila pemerintah memiliki keinginan yang baik untuk melaksanakannya. Pemerintah mendorong dan memberikan kesempatan kepada masyarakat untuk terlibat dalam pola partisipatif ini. Pola ini membuat masyarakat semakin berdaya dan ikut menikmati kue pertumbuhan ekonomi yang dihasilkan dari proses pembangunan yang dilaksankan. Pertumbuhan ekonomi yang berkualitas menjadikan pembangunan yang dilaksanakan oleh pemerintah bersama seluruh komponen bangsa mampu meningkatkan kesejahteraan masyarakat secara luas sesuai dengan apa yang menjadi tujuan dari pada pembangunan nasional itu sendiri.

Pembangunan nasional yang diimbangi dengan partisipasi masyarakat yang aktif atau dengan masyarakat yang berdaya akan menghasilkan kekuatan yang mampu mewujudkan tujuan nasional sesuai yang di cita-citakan. Proses pelaksanaan pembangunan yang dilaksankan dengan pola partisipatif yakni pola pembangunan yang mulai dari proses perencanaan sudah melibatkan seluruh komponen masyarakat secara partisifatif diyakini akan mampu mewujudkan pertumbuhan ekonomi yang tinggi dan berkualitas. Pertumbuhan yang tinggi saja belum cukup mengurangi tingkat kemiskinan di negeri ini. Untuk itu pertumbuhan yang tinggi dan berkualitas sangat diperlukan, karena pertumbuhan yang berkualitas mengandung arti bahwa pertumbuhan ekonomi yang terjadi 
dinikmati oleh sebagian besar masyarakat.

Masyarakat berdaya akan mampu mewujudkan tujuan pembangunan yakni masyarakat yang sejahteran.

\section{F. Penutup}

Partisipasi masyarakat dalam proses pembangunan merupak kunci utama suksesnya pelaksanaaan pembangunan tersebut. Partisipasi masyarakat akan menempatkan masyarakat sebagai motor penggerak atau sebagai subyek pembangunan bukan hanya sebagai obyek atau penerima manfaat saja. Dengan Partisispasi ini membuat masyarakat akan merasa memiliki serta ikut bertanggungjawab terhadap setiap proses dan hasil-hasil pembangunan. Partisipasi masyarakat akan mengarah kepada pemberdayaan masyarakat karena melalui partisipasi dalam seluruh proses, masyarakat akan semakin berdaya dan mampu mengendalikan proses tersebut kearah pencapaian kesejahteraan masyarakat itu sendiri.

Masyarakat yang partisipatif dalam proses pembangunan mengandung arti bahwa masyarakat berinisiatif memulai proses kegiatan untuk perubahan kearah yang lebih baik. Pertisipasi masyarakat hanya bisa terjadi apabila warganya ikut aktif. Jumlah penduduk yang banyak serta diimbangi dengan partisipasi yang tinggi membuat penduduk menjadi kekuatan besar dalam segala kegiatan berbangsa dan bernegara. Hal ini akan menjadi modal dan kekuatan untuk mensukseskan pembangunan nasional.

Mendorong partisipasi masyarakat dalam membangun Indonesia dari daerah akan terwujud apabila pemerintah memiliki keinginan yang kuat untuk melaksanakannya. Pemerintah wajib mendorong dan memberikan kesempatan kepada masyarakat untuk terlibat dalam pola partisipatif ini. Pola ini membuat masyarakat semakin berdaya dan ikut menikmati kue pertumbuhan ekonomi yang dihasilkan dari proses pembangunan yang dilaksankan. Pertumbuhan ekonomi yang berkualitas menjadikan pembangunan yang dilaksanakan oleh pemerintah bersama seluruh komponen bangsa mampu meningkatkan kesejahteraan masyarakat secara luas sesuai dengan apa yang menjadi tujuan dari pada pembangunan.

\section{Daftar pustaka}

Hakim, Lukman. 2011. Pengantar Administrasi Pembangunan. Jogjakarta. Ar-Ruzz Media.

Kaho, J.R. 1997. Prospek otonomi di Negara Republik Indonesia. Jakarta. PT Raja Grafido persada.

Mardiasmo. 2018. Otonomi \& Manajemen Keuangan Daerah. Yogyakarta. Penerbit Andi.

Siagian. $\quad$ S. $\quad$ P. 1983, Administrasi Pembangunan : Konsep, Dimensi dan Strateginya, Jakarta, PT Gunung Agung

Suhandak dan Nugroho, Trilaksono. 2007. Paradigma Baru Pengelolaan Keuangan daerah dalam Penyusunan APBD di Era Otonomi. Malang. Lembaga Penerbitan dan Dokumentasi FIA-UNIBRAW.

Sukirno, Sadono. 2007,Ekonomi Pembangunan, Jakarta,KencanaPrenada Media Group

Sumarto, Sudarno, Asep Suharyadi, Alex Arifianto. 2004. Tata Kelola 
Pemerintahan dan Penanggulangan Kemiskinan : Bukti-bukti Awal Desentralisasi di Indonesia. Jakarta. Lembaga Penelitian SMERU.

Suprayitno, Bambang. 2017. Ekonomi Publik; Konsep dan Implementasi Kebijakan. Yogyakarta.UPP STIM YKPK

Todaro, Michael P. Dan Stephen C Smith,. 2004. Pembangunan Ekonomi di
Dunia Ketiga, edisi kedelapan. Jakarta. Penerbit Erlangga.

Undang-Undang Dasar Republik Indonesia dan Perubahannya, (Amandemen I, II, III dan IV), Penabur Ilmu.

Wiratma, Leo I Made, Djadijono M, Legowo TA.editors.2007. Membangun Indonesia Dari Daerah, Partisipasi Publik dan Politik Anggaran Daerah. Jakarta. CSIS. 